() М. В. Сірик, асистент, КПІ ім. Ігоря Сікорського, Київ, Україна

\title{
МІСЬКА ПРОГРАМА ПІДТРИМКИ КНИГОВИДАННЯ КИЕВА: РЕТРОСПЕКТИВНИЙ АНАЛІЗ ТА СУЧАСНИЙ СТАН
}

\author{
У статті проведено ретроспективний аналіз видавничої \\ діяльності Київської міської державної адміністрації, \\ розглянуто програму «Київ інформаційний» у частині \\ видавничої діяльності, роботу Видавничої ради \\ Департаменту суспільних комунікацій Київської \\ міської державної адміністрації.
}

\section{Ключові слова: книговидання; державна підтримка; Київ інформаційний; бібліотека; видавнича рада.}

\section{Постановка проблеми}

Державна допомога у сфері сприяння культурі та збереженню культурної спадщини є поширеною в країнах Європейського Союзу. В Україні така практика теж має місце. Розглянемо, як саме це відбувається на рівні країни та міста.

\section{Аналіз попередніх досліджень}

Дослідженнями державної підтримки книговидання, заходами сприяння розвитку видавничо-поліграфічної галузі займалися Я. В. Котляревський, О. В. Мельников, А. М. Штангрет, Л. А. Швайка, В. В. Шляхетко [1-4]. Ученими детально досліджено питання державної підтримки на податковому рівні та цільового фінансування на рівні держави. Питання ж підтримки на міському рівні потребує додаткового дослідження.

(c) $2018 p$
Метою роботи $€$ аналіз видавничої діяльності Київської міської державної адміністрації протягом 2000-2018 рр., дослідження роботи Видавничої ради Департаменту суспільних комунікацій Київської міської державної адміністрації.

\section{Результати проведених досліджень}

На загальнодержавному рівні України основною програмою підтримки книговидання $€$ «Українська книга», що була прийнята у 2005 р. [5].

Видання, надруковані за кошти державного бюджету за програмою «Українська книга», направляються до публічних бібліотек, культурно-просвітницьких товариств національних меншин, дипломатичних представництв України та українських громад за кордоном і для задоволення інших загальнодержавних потреб.

Програми підтримки книговидання $€$ також на рівні областей 


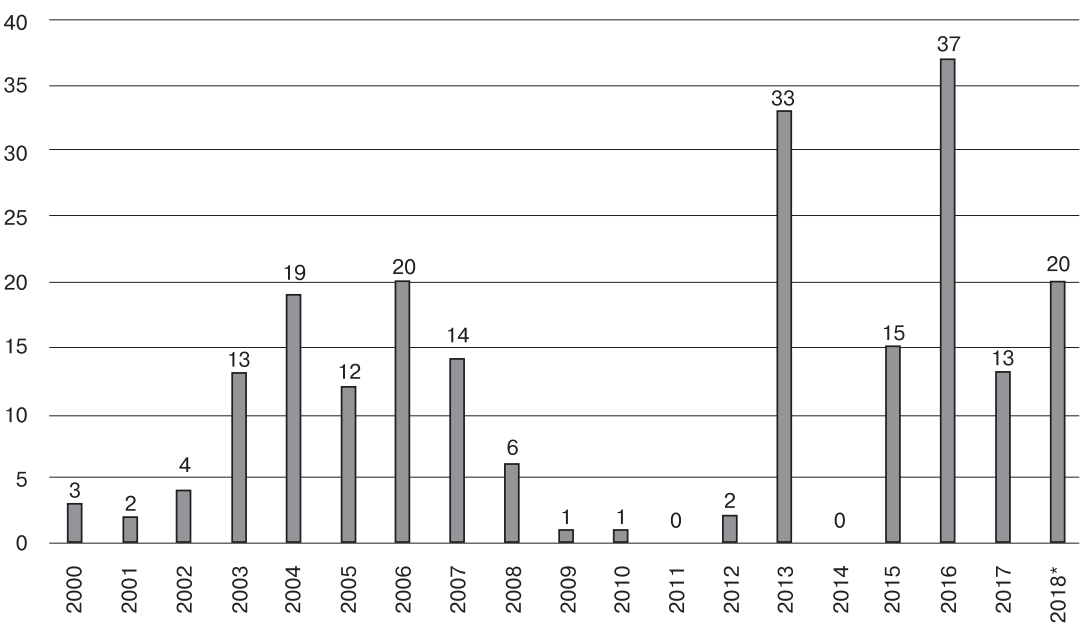

Рис. 1. Динаміка випуску назв книг за кошти бюджету м. Києва за 2000-2018 рр. (2018 р. - прогнозне значення).

Складено автором за [6]

і міст. Розглянемо книговидавничу діяльність міст на прикладі Києва. Органом, який забезпечує здійснення програми підтримки книговидання в м. Києві, є Київська міська державна адміністрація (КМДА). Проаналізуємо видавничу діяльність КМДА починаючи з 2000 р. Динаміка випуску назв книг за період з $2000 \mathrm{p}$. по 2018 р. наведена на рис. 1, а фінансування видавничої діяльності з 2007 р. по 2018 р. - на рис. 2.

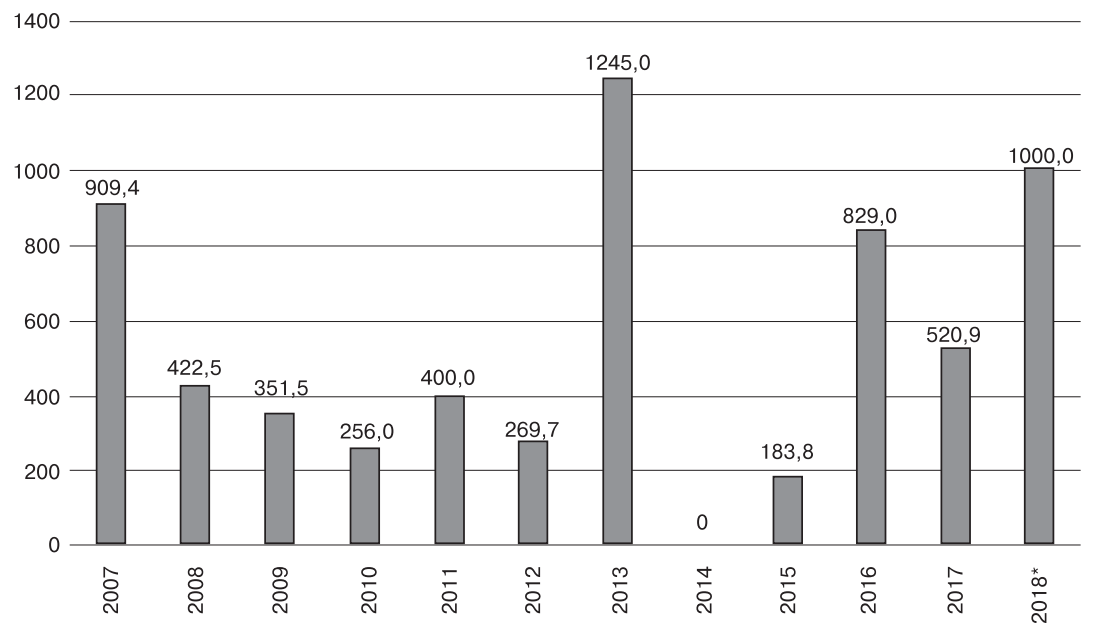

Рис. 2. Динаміка фінансування випуску книг за кошти бюджету м. Києва за 2007-2018 рр. (2018 р. - прогнозне значення). Складено автором на основі [7] та даних, отриманих особисто в Департаменті суспільних комунікацій КМДА 
Протягом 2000-2010 рр. було видано 93 книги загальним накладом майже 100 тис. примірників. У цей період найбільша кількість видань випускалася з 2003 р. по 2008 р., після чого було скорочено фінансування програми та зменшено кількість видань. З 2011 р. прийнято міську програму «Київ інформаційний» на 20112015 рр., яка включала, серед інших, заходи для популяризації читання та підтримки книговидання [8]. Фінансування програми наведено на рис. 2 з якого видно, що гроші виділялися нерівномірно. У 2011 р. вся сума була спрямована на погашення заборгованості, а у 2014 р. кошти не було виділено зовсім. Найбільш продуктивним роком за час дії програми став 2013 р., коли було видано 33 книжки загальною вартістю 1245 тис. грн. За програмою видавалися здебільшого книги, які розповідали читачам про історію та сучасність міста Києва й розповсюджувалися серед київсь-КИх i національних бібліотек.

у 2015 р. Наказом № 51 від 23.04.2015 р. Департаменту суспільних комунікацій Київської міської державної адміністрації [9] було створено Видавничу раду при Департаменті суспільних комунікацій КМДА, завданням якої $€$ встановлення критеріїв та відбір творів для друку за програмою «Київ інформаційний» з метою задоволення читацького попиту жителів м. Києва. Цього ж року Видавничою радою було відібрано й рекомендовано до друку 15 творів на загальну суму 183,8 тис. грн. Дію програми «Київ інформаційний» на 2011-2015 рр. було продовжено на 2016-2018 рр. [10].
32016 р. із загального бюджету на книговидання було виділено 200 тис. грн на збірки та антології творчих спілок. Продовжила свою роботу й Видавнича рада, рекомендувавши до друку в 2016 р. 37 книжок загальною вартістю 829 тис. грн. (з них 4 збірки творчих спілок). У 2017 р. було видано 13 книжок загальною вартістю 520,9 тис. грн. (з них 3 збірки творчих спілок).

Незвичним та актуальним виданням 2016 р. стала книжка для школярів «Країно моя вишивана» Олени Комової, надрукована шрифтом Брайля паралельно 3 повноколірним друком для зрячих дітей. Шрифтом Брайля було відтворено не лише текст, а й орнаменти вишивки.

Знаковим виданням 2017 р. стала книжка Дмитра Малакова та Андрія Прибєги «Київ столітньої давнини» - ілюстроване видання пропонує читачеві цікаву екскурсію містом початку XX ст., проілюстроване колекцією поштівок столітньої давнини.

Динаміка середніх накладів книжок наведена на рис. 3.

Найбільший середній наклад книг був у 2000-2001 рр., що зумовлено виданням малої кількості назв, окремі з яких мали наклад 5000 та 3500 примірників. З 2002 р. по 2010 р. середній наклад знаходиться в межах від 825-и до 1333-х примірників. Це спричинено тим, що більшість назв книжок надруковано накладами в 1 тис. примірників, і лише окремі видання мали більший або менший наклад. у 2012 р. було видано дві книги, одна з яких вийшла накладом 1 тис. примірників, а інша - 
3 тис. примірників. У 2013 р. книжки виходили накладами від 500 до 2000 примірників.

З 2015 р. Видавничою радою за умови обмеженого фінансування та з урахуванням потреби бібліотечної мережі м. Києва було прийнято рішення про зменшення накладів видань. Так, для прозових творів затверджено наклад 500 примірників, а для поезії - 300 примірників. Це дало змогу видавати більше назв книжок в умовах здорожчання поліграфічних послуг.

Щороку Видавнича рада визначає тематику рукописів, які виносяться на розгляд. Так, у 2015 р. приймалися твори, які стосувалися Києва, крім того, це мала бути перша книжка автора-киянина.

у 2016 р., незважаючи на збереження загальної рекомендації про київську тематику для творів, також розглядалися твори й іншої тематики. Рукописи могли подавати автори, які вже видавалися, проте подавати вони мали не опублікований раніше рукопис. Також було введено шифрування творів, щоб експерти не знали авторів під час розгляду рукописів.

Слід зазначити, що це єдина міська програма підтримки книговидання в Україні, де приймаються рукописи безпосередньо від авторів, а не від видавництв, що дає можливість відкрити нові імена.

Редакційно-видавничу обробку та друк видань за вказаною програмою здійснювали як державні видавничо-поліграфічні підприємства, так і приватні. Вибір виконавця робіт відбувався шляхом проведення тендеру. За бажанням автора твору та за його кошти поліграфічне підприємство може надрукувати більший наклад, ніж вказано в тендері. Оскільки додрукарська підготовка повністю оплачена державою, вартість додаткового накладу

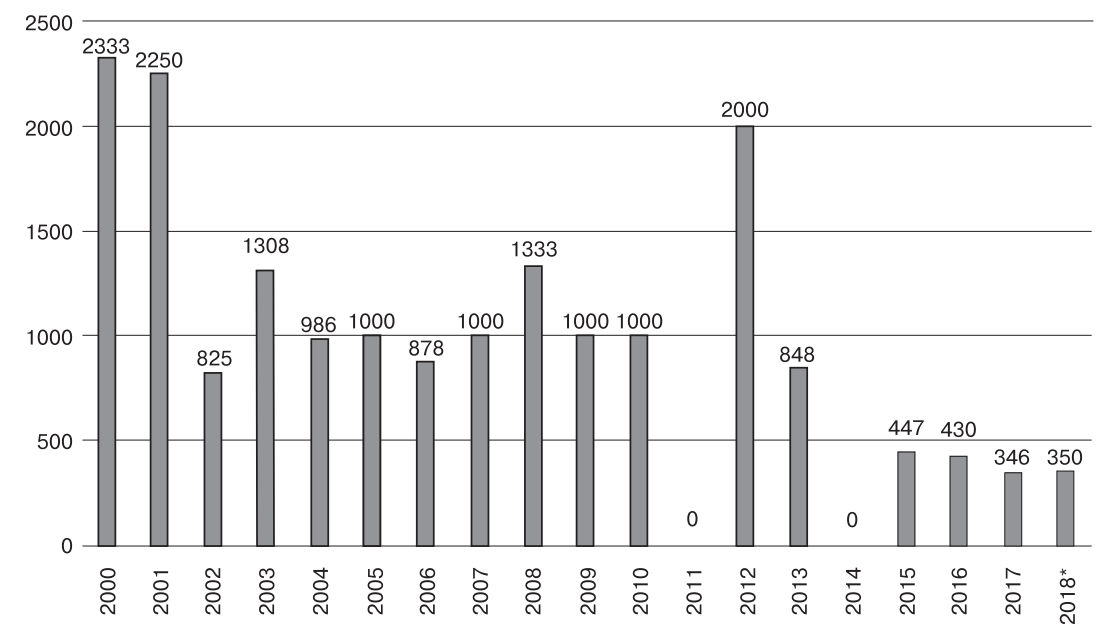

Рис. 3. Динаміка середнього накладу книг, виданих за кошти бюджету м. Києва за 2000-2018 рр. (2018 р. - прогнозне значення).

Складено автором за [6] 
для автора буде значно нижчою, аніж за умов оплати повного виробничого циклу.

Видані книжки за програмою «Київ інформаційний» передаються до Публічної бібліотеки ім. Лесі Українки, звідки розподіляються до бібліотек м. Києва.

Загалом з 2000 р. по 2017 р. за кошти бюджету м. Києва видано 195 назв книжок загальним накладом 163 тис. примірників.

\section{Висновки}

На основі проведеного дослідження можна стверджувати, що підтримка книговидання в м. Києві є дієвою, хоча обсяг їі фінансування недостатній. За проаналізований період видано серед іншого й книгу для читачів з обмеженими можливостями шрифтом Брайля. Також висвітлено історію й сьогодення міста. Ефективність роботи Видавничої ради при Департаменті суспільних комунікацій КМДА доводить статистика видачі літератури міськими бібліотеками: за 10 місяців 2017 року зареєстровано понад 10 тис. книговидач, які видані за програмою у 2016 р. Доцільним є збільшення фінансування з метою розширення асортименту видань та оновлення фондів міських бібліотек.

\section{Список використаної літератури}

1. Ключові аспекти розвитку підприємництва у видавничо-поліграфічній галузі України / А. М. Штангрет, В.В.Шляхетко // Формування ринкових відносин в Україні. 2008. № 8. С. 61-65.

2. Мельников О. В. Державна підтримка видавничої справи: сучасний стан та перспективи // Printus.com.ua - социальная сеть полиграфистов. URL: https://printus.com.ua/article/read/3576.

3. Основні засади діяльності Державного комітету з питань телебачення і радіомовлення України як суб'єкта інформаційної сфери / я. В. Котляревський, А. М. Штангрет, О. В. Мельников // Держава та регіони. Сер. Економіка та підприємництво. 2015. № 5(86). С. 15-22.

4. Швайка Л. А. Розвиток і регулювання видавничого підприємництва: монографія. Львів: Укр. академ. друкарства, 2005. 432 с.

5. Про затвердження Порядку реалізації бюджетної програми «Випуск книжкової продукції за програмою „Українська книга“»: Наказ від 28.11.2012 № 313 за станом на 05.07.2016 // База даних «Законодавство України» / Держкомтелерадіо України. URL: http://zakon3.rada.gov.ua/laws/ show/z2087-12.

6. Книги, випуск та друк яких було профінансовано з бюджету м. Києва в 2000-2017 роках // Департамент суспільних комунікацій виконавчого органу Київської міської ради (Київської міської державної адміністрації). URL: http://dsk.kievcity.gov.ua/content/allbooks.html.

7. Київ хоче повернути статус найбільш читаючого міста України // Вечірній Київ. 2017. 12 січ. С. 8-9.

8. Про затвердження міської цільової програми на 2011-2015 роки «Київ інформаційний»: Рішення Київської міської ради від 15.12.2011 № 841/7077 за станом на 21.02.2013 // Департамент суспільних комунікацій виконавчого органу Київської міської ради (Київської міської державної адміністраціï). URL: http://dsk.kievcity.gov.ua/files/2015/4/29/Kyiv-info-2011-2015.pdf. 
9. Про Видавничу раду при Департаменті суспільних комунікацій виконавчого органу Київської міської ради (Київської міської державної адміністрації): Наказ Департаменту суспільних комунікацій виконавчого органу Київської міської ради (Київської міської державної адміністрації) від 23.04.2015 № 51 // Департамент суспільних комунікацій виконавчого органу Київської міської ради (Київської міської державної адміністрації). URL: http://kievcity.gov.ua/done img/f/\%D0\%9D\%D0\%B0\%D0\%BA\%D0\% B0\%D0\%B7\%D0\%94\%D0\%A1\%D0\%9A-\%D0\%9A\%D0\%9C\%D0\%94\% D0\%90-51-23042015.pdf.

10. Про затвердження міської цільової програми на 2016-2018 роки «Київ інформаційний»: Рішення Київської міської ради від 14.04.2016 № 333/333 // Хрещатик. 2016. 6 трав. URL: http://www.kreschatic.kiev.ua/file/ 11702.pdf.

\section{References}

1. Shtanhret, A. M. \& Shliakhetko, V. V. (2008). Kliuchovi aspekty rozvytku pidpryiemnytstva u vydavnycho-polihrafichnii haluzi Ukrainy. Journal of Formuvannia rynkovykh vidnosyn v Ukraini, 8, 61-65 [in Ukrainian].

2. Melnykov, O. V. Derzhavna pidtrymka vydavnychoi spravy: suchasnyi stan ta perspektyvy. Printus.com.ua - sotsyalnaia set polyhrafystov. Retrieved from https://printus.com.ua/article/read/3576 [in Ukrainian].

3. Kotliarevskyi, Ya. V. \& Shtanhret, A. M. \& Melnykov, O. V. (2015). Osnovni zasady diialnosti Derzhavnoho komitetu z pytan telebachennia i radiomovlennia Ukrainy yak sub'iekta informatsiinoi sfery. Journal of Derzhava ta rehiony. Ser. Ekonomika ta pidpryiemnytstvo, 5(86), 15-22 [in Ukrainian].

4. Shvaika, L. A. (2005). Rozvytok I rehuliuvannia vydavnychoho pidpryiemnytstva. Lviv: Ukr. akadem. drukarstva, 432 [in Ukrainian].

5. Pro zatverdzhennia Poriadku realizatsii biudzhetnoi prohramy 'Vypusk knyzhkovoi produktsii za prohramoiu 'Ukrainska knyha'”. Nakaz vid 28.11.2012. № 313 za stanom na 05.07.2016. Baza danykh 'Zakonodavstvo Ukrainy'. Derzhkomteleradio Ukrainy. Retrieved from http://zakon3.rada.gov.ua/laws/ show/z2087-12 [in Ukrainian].

6. Knyhy, vypusk ta druk yakykh bulo profinansovano z biudzhetu m. Kyieva v 2000-2017 rokakh. Departament suspilnykh komunikatsii vykonavchoho orhanu Kyivskoi miskoi rady (Kyivskoi miskoi derzhavnoi administratsii). Retrieved from http://dsk.kievcity.gov.ua/content/allbooks.html [in Ukrainian].

7. Kyiv khoche povernuty status naibilsh chytaiuchoho mista Ukrainy (2017). Newspaper Vechirnii Kyiv, 12 sich., 8-9 [in Ukrainian].

8. Pro zatverdzhennia miskoi tsilovoi prohramy na 2011-2015 roky 'Kyiv informatsiinyi'. Rishennia Kyivskoi miskoi rady vid 15.12.2011 № 841/7077 za stanom na 21.02.2013. Departament suspilnykh komunikatsii vykonavchoho orhanu Kyivskoi miskoi rady (Kyivskoi miskoi derzhavnoi administratsii). Retrieved from http://dsk.kievcity.gov.ua/files/2015/4/29/Kyiv-info-20112015.pdf [in Ukrainian].

9. Pro Vydavnychu radu pry Departamenti suspilnykh komunikatsii vykonavchoho orhanu Kyivskoi miskoi rady (Kyivskoi miskoi derzhavnoi administratsii). Nakaz Departamentu suspilnykh komunikatsii vykonavchoho orhanu Kyivskoi miskoi rady (Kyivskoi miskoi derzhavnoi administratsii) vid 23.04.2015 № 51. 
Departament suspilnykh komunikatsii vykonavchoho orhanu Kyivskoi miskoi rady (Kyivskoi miskoi derzhavnoi administratsii). Retrieved from http://kievcity.gov.ua/done img/f/\%D0\%9D\%D0\%B0\%D0\%BA\%D0\%B0\%D0\%B7\%D0\%9 4\%D0\%A1\%D0\%9A-\%D0\%9A\%D0\%9C\%D0\%94\%D0\%90-51-23042015.pdf [in Ukrainian].

10. Pro zatverdzhennia miskoi tsilovoi prohramyna 2016-2018 roky 'Kyiv informatsiinyi'. Rishennia Kyivskoi miskoi rady vid 14.04.2016 № 333/333 (2016). Newspaper of Khreshchatyk, 6 trav. Retrieved from http://www. kreschatic.kiev.ua/file/11702.pdf [in Ukrainian].

В статье проведен ретроспективный анализ издательской деятельности Киевской городской государственной администрации, рассмотрена программа «Киев информационный» в части издательской деятельности, работа Издательского совета Департамента общественных коммуникаций Киевской городской государственной администрации.

\section{Ключевые слова: книгоиздание; государственная поддержка; Киев информационный; библиотека; издательский совет.}

The article publishing a retrospective analysis of the Kyiv city state administration considered the program 'Kyiv Informatsiinyi' in terms of publishing, the publishing board of the Department of Social Communication of the Kyiv City State Administration.

Keywords: book publishing; state support; Kyiv Informational; library; publishing council. 